\title{
The Effectiveness of the E-Module of Economics Learning on Problem-Based Learning used to Improve Students' Learning Outcomes
}

\author{
Ahmad Jaenudin ${ }^{1}$, Baedhowi ${ }^{1}$, Tri Murwaningsih ${ }^{1}$ \\ ${ }^{1}$ Department of Economics Education, Sebelas Maret University, Surakarta, Indonesia, \\ ahmadjaenudin4793@gmail.com
}

\begin{abstract}
The rapid development of technology and science brings influence on education. it requires planning in conducting learning process utilizing technology advances. One of the ways is the utilization of teaching media such e-module as electronic learning material that is practically used in learning process. This article aims to develop the Emodule of Economics learning based Problem-based Learning to improve students' learning outcomes. The method used in writing this article is literature review of relevant research journals. Commonly, the problem is that learning tends to be conventional and lack of learning media utilization, so that students are less interested to understand learning material which influences on low learning outcomes. One of media that can be used is E-module based Problem-based Learning as learning innovation. E-module based Problem-based Learning is one of the innovative media that involve students actively. The utilization of E-module based Problem-based Learning gives in-depth concept understanding on the cognitive, affective, and psychomotor domains that support critical thinking and problem-solving abilities which improve students' learning outcome.
\end{abstract}

Keywords: E-Module; Problem-based learning; learning outcomes

\section{INTRODUCTION}

The rapid development of technology and science brings influences in many sectors. One of them is in education. Learning demand that emphasizes maximal utilization of learning tools requires a plan in learning. Lesson plan is indispensable to fulfill students' needs. All of supporting aspects in lesson plan must be provided to support the achievement of maximal learning outcome. The planning is constructed involving instructional design components that include instructional objective which is started from instructional analysis, context and students analysis, formulating performance target, assessment instrument development, developing learning strategy, developing and selecting material, and developing as well as conducting formative and summative evaluations [1]. The existing problem in learning is the conventional learning that utilizes less learning media. Therefore, the effectiveness of learning is determined by how far the teacher conducted the readiness of planning. Media utilization in learning can be a tool and help the teacher in learning process. According 
to $[2,3,4,5]$ teaching media is an intermediary tool, aids in learning process to stimulate thought, attention, and students' willingness to enhance the effectiveness and efficiency in achieving learning objectives. One of media utilizations is E-module utilization in learning.

E-module is teaching material that is systematically designed based on particular curriculum and packaged in particular time unit, which is displayed using electronic devices such as, computer or android [6]. E-module utilization that combines technology development and learning can provide a new learning experience in building students' knowledge. This is in line with DeWitt et. Al (2014) who state that using module in learning is effective to give interaction insights and develop students' knowledge [7]. Besides the use of teaching media, it is required learning strategy by collaborating media and teaching model. One of teaching models that can be used is problem-based learning, a model that allows the students to accomplish authentic problem that aims to create their knowledge, develop inquiry and higher skills, and develop independence and confidence [8].

Electronic module that is integrated with problem-based learning provides innovative learning source for students, so that learning is more effective, interesting, and makes the students study actively to achieve learning objectives. In relation to the concept, it is argue that learning using e-module integrated with problem-based learning is effective to apply in learning [9]. E-module can be designed referring to problembased learning syntax. E-module based problem-based learning has stages based on problem-based learning that consists of students' orientation on problem, organizing students to research, helping independent and group investigations, developing and presenting results, as well as analysing and evaluating problem-solving process [10].

\section{DISCUSSIONS}

\section{E-Module}

E-module or electronic module is digital learning media device or non-printed that is constructed systematically for independent learning needs. So that it demands the students to solve the problem in their own way [12]. Dimhad [13] state that e-module is a part of electronic-based e-learning in which the learning utilizes information technology and communication, specifically electronic device. It means that not only internet, but also all of electronic devices such as film, cassette video, OHP, slide, LCD projector and tape set. That is in line with Suarsana et.al (2013) who states that media is used as aids by the teacher as the evidence of classroom effectiveness and substitutional media in learning media system [14]. Electronic module is a module based TIK (Communication Information Technology). Compared to printed module is that its interactive term ease navigation, allow the user to display/load images, audio, video, and animation as well as it is completed by test/formative quiz that allows automatic feedback immediately [15].

Dealing with several assumptions above, it can be concluded that electronic module is an electronic learning material that us systematically constructed which aims to create interactive learning accompanied with animation that supports the learning for interesting learning process. 


\section{Problem-based Learning}

Problem-based learning has been recognized as an active learning development and students-centred learning approach that use unstructured problems (real problems or complex simulation problems) as the starting point and anchor for learning process [16]. This learning begins with students' restricted knowledge, then doing pair collaboration, researcher, and conducting expert consultation to generate an explanation about completion or problems solution [17].

The goals of PBL are helping students to develop investigative skill and solving problem skill, giving experience of adult role to the students and improving students' confidence in their ability to think and become self-regulated [18]. Another finding shows that with a good design, PBL can create learning context that encourages students to express academic potential [19]. Besides, the effect of learning process using PBL can improve students' interests and learning motivation [20]. Problem-based learning is related to constructivism theory that facilitates the students to improve their critical thinking abilities through scaffolding process [21].

Problem-based learning is designed to help the students to improve their critical thinking skill, problem-solving skill, and intellectual skill by experiencing it in real situation or simulated situation as well as become independent and autonomy students. Problem offered to the students will provide new knowledge. In relation to the definition of Problem-based Learning, it is argue that PBL refers to a learning approach that focuses on the process of solving a problem by which learners required knowledge. PBL refers to learning approach that focuses on problem-solving in which students get the required knowledge [22]. According to Hou (2014), the characteristic of PBL are 1) problem is the starting point of learning process; 2) problem can be provided by teacher or problem can be found by students in daily life [23]. One of advantages of PBL method is that students have chance to get involved actively in solving problems so that, they will be motivated in learning process. [24].

Based on several assumptions above, it can be concluded that PBL model is a learning model that emphasizes on problem-solving process that is as close as possible to real life as the context for the students to think, problem-solving skill and getting knowledge.

\section{The Stages of Problem-based Learning Model}

There are five phases in conducting problem-based learning model, as shown on Table I below: 
TABLE I. THE STAGES OF PROBLEM-BASED LEARNING

\begin{tabular}{ll}
\hline \multicolumn{1}{c}{ Phase } & \multicolumn{1}{c}{ Teachers' Activity } \\
\hline $\begin{array}{l}\text { Phase 1: Giving problem } \\
\text { orientation to the students }\end{array}$ & $\begin{array}{l}\text { Discussing learning objectives, describing and motivating } \\
\text { students to get involved in problem-solving activity }\end{array}$ \\
\hline $\begin{array}{l}\text { Phase 2: Organizing students to } \\
\text { research }\end{array}$ & $\begin{array}{l}\text { Helping students to define and organize learning tasks } \\
\text { related to the problems. }\end{array}$ \\
\hline $\begin{array}{l}\text { Phase 3: helping independent and } \\
\text { group investigation. }\end{array}$ & $\begin{array}{l}\text { Encouraging the students to get appropriate information, } \\
\text { conduct experiment, and to find explanation and solution. }\end{array}$ \\
\hline $\begin{array}{l}\text { Phase 4: Developing and presenting } \\
\text { the results. }\end{array}$ & $\begin{array}{l}\text { Teacher helps the students to plan and prepare appropriate } \\
\text { results such as report, video recording, and models in } \\
\text { helping them deliver the result to others. }\end{array}$ \\
\hline $\begin{array}{l}\text { Phase 5: Analysing and evaluating } \\
\text { problem-solving process }\end{array}$ & $\begin{array}{l}\text { Teacher helps the students to reflect their investigation and } \\
\text { applied processes. }\end{array}$ \\
\hline
\end{tabular}

(Source: Arends, 2008: 406)

\section{Learning Outcomes}

Learning outcome is someone's behavioural changes as the result of someone's interactions with the environment [26]. Changes of each student can be seen and judged by students' learning outcomes after participating learning activities. Those changes are the result of someone's interaction her or his environment. According to [26], learning outcome is students' skill after receiving learning experience. Learning outcome is students' achievement in the current time that they did not get previously, or a change on someone as the result of learning experience [27].

Learning outcomes are statements which are used to describe specifically what is expected from a learner in form of understanding, knowledge and know-how at the end of a certain period of learning [28]. Someone is considered success in learning if he or she can show the changes in her or him [29]. Those changes include such as thinking ability, skill, or attitude to particular object. In addition, it is point out that learning outcomes often cited in the literature (a) cognitive learning, (b) behavioural learning, and (c) affective learning [30].

Dealing with the assumptions above, it can be concluded that learning outcome is the achievement of the interaction between students and teacher in the classroom that can influence students' attitude such as attitude thinking ability and students' skill.

\section{Electronic Module of Economics Learning Based Problem-based Learning}

The use of problem-oriented e-module will guide the students to find problem solution independently and this will provide concrete experience in solving problem which then arises and train high thinking skill including critical thinking skill [31]. Through e-module learning based Problem-based Learning, students share and express argument and have further possibilities to fix misconception during discussing the encountered problem [32].

Electronic module of Economics learning based Problem-based Learning emphasizes on Economics learning process that releases the students to get involved 
actively in learning such as problems finding. Problem-based learning process is a learning in which the students conduct an authentic problem that aims to compile their own knowledge, inquiry development, and higher skill, developing the independence and confidence [33]. In line with this, it states that the use of learning model problembased can improve students' creativity, democracy and learning outcomes [34]. Emodule based problem-based learning is designed to help students in improving critical thinking skill, problem-solving and intellectual skills by experiencing it through the real or simulated situation as well as to become independent students so that learning achievement can be maximal. Related to this, it is mention that the use of electronic module and printed module can improve students' learning outcomes [35].

E module based problem-based learning (PBL) can be utilized for independent learning with minimal teacher's help or guidance. Using e-module in learning allows the students to have high speed in learning that can accomplish one or more basic competence quickly compared to other students [36]. The development of independent teaching material or module, the stages are planning writing, reviewing and revising, and finalization [37]. Besides, a module can be considered as teaching material in which the reader can learn independently. The development of electronic module must pay attention to the principle, needs analysis and environment condition in order that the electronic module can be really beneficial for the students. The development of electronic module must be interesting so that it can improve learning outcome and achieve expected competence effectively.

\section{CONCLUSION}

Based on this literature study, it can be concluded that lesson plan is required to achieve an effective and interesting learning. The use of media in learning becomes one of effective ways that is combined with learning model which demands the students to be active. One of learning media and models that can be utilized in learning is Emodule based problem-based learning. The application of E-module based problembased learning can be utilized to support the effectiveness of learning so that learning situation becomes interesting and students are motivated. The use of E-module media of Economics learning based problem-based learning is expected will help the reach of learning objectives and maximal learning outcomes.

\section{REFERENCES}

[1] Dick, W., Carey, L., \& Carey, J. O. The Systematic Design of Instruction: Sixth Edition (p. 1). New York: Pearson. (2005).

[2] Arsyad, A. (2010). Media Pembelajaran. Jakarta: PT Rajagrafindo Persada.

[3] Daryanto. (2011). Media Pembelajaran. Bandung: PT Sarana Tutorial Nurani Sejahtera.

[4] Miarso, Y. (2004). Menyamai Benih Teknik Pendidikan. Jakarta: Kencana.

[5] Sanaky, H. (2013). Media Pembelajaran Interaktif-Inovatif. Yogyakarta: Kaukaban Dipantara

[6] Fausih, M., \& Tandyonomanu, D. (2015). Pengembangan Media E-Modul Mata Pelajaran Produktif Pokok Bahasan "Instalasi Jaringan LAN (Local Area Network)" Untuk Peserta didikKelas XI Jurusan Teknik Komputer Jaringan Di SMK Negeri 1 Labang Bangkalan Madura. Jurnal Online Universitas Negeri Surabaya, 1 (1), 1-9.

[7] DeWitt, D., Siraj, S., \& Alias, N. (2014). Collaborative mLearning: A Module for Learning Secondary School Science. Educational Technology \& Society, 17 (1), 89-101. 
[8] Arends, R. I. (2008). Learning to Teach Belajar untuk Mengajar Edisi 7 Jilid 1. Terj. H.P. Soejipto \& S. M. Soejipto. Yogyakarta: Pustaka Belajar.

[9] Farenta, A. S., Sulton , \& Setyosari, P. (2016). Pengembangan E-Module Berbasis Problembased Learning Mata Pelajaran Kimia Untuk Siswa Kelas X SMA Negeri 8 Malang. Education Journal, 1 (6), 1159-1168.

[10] Masek, A \& Yamin, S. (2010). Problem-based Learning: A Collection from the Literature. Journal of Asian Social Science, 6(8): 148-158.

[11] Ariasa, K., Santyadiputra, G. S., \& Sindu, I. G. P. (2016). Pengembangan E-Modul Berbantuan Media CAI Pada Mata Pelajaran Fotografi Kelas X Desain Komunikasi Visual di SMK Negeri 1 Sukasada. Jurnal Nasional Pendidikan Teknik Informatika, 5 (3), 127 - 135.

[12]Fausih, M., \& Tandyonomanu, D. (2015). Pengembangan Media E-Modul Mata Pelajaran Produktif Pokok Bahasan "Instalasi Jaringan LAN (Local Area Network)" Untuk Peserta didikKelas XI Jurusan Teknik Komputer Jaringan Di SMK Negeri 1 Labang Bangkalan Madura. Jurnal Online Universitas Negeri Surabaya, 1 (1), 1-9.

[13] Taiwo, S. (2009). Teachers' Perception of The Rule of Media In Classroom Teaching In Secondary Schools. The Turkish Online Journal of Educational Technology-TOJET, 8 (1), 75 83.

[14] Suarsana, I. M., \& Mahayukti, G. A. (2013). Pengembangan E-Modul Berorientasi Pemecahan Masalah untuk Meningkatkan Keterampilan Berpikir Kritis Mahasiswa. Jurnal Pendidikan Indonesia, 2 (2), 264 - 275.

[15] Tan, Oon-seng. 2004. Cognition, Metacognition, and Problem-based Learning, in Enhancing Thinking Through Problem-based Learning Approaches. Singapore: Thomson Learning.

[16] Smaldino, Sharon, E., Deborah, L.L., \& James, D. R. (2014). Instructional Technology and Media for Learning: Teknologi Pembelajaran dan Media untuk Belajar Edisi 9. Terj. A. Rahman. Jakarta: Kencana Prenadamedia Group.

[17] Arends, R. I. (2008). Learning to Teach Belajar untuk Mengajar Edisi 7 Jilid 1. Terj. H.P. Soejipto \& S. M. Soejipto. Yogyakarta: Pustaka Belajar.

[18] Gallagher, S. A., \& Gallagher, J. J. Using Problem-based Learning to Explore Unseen Academic Potential. Interdisciplinary Journal of Problem-based Learning . (2013), p. 111

[19] Jones, B. D., Epler, C. M., Mokri, P., \& Bryant, L. H. The Effects of a Collaborative Problembased Learning Experience on Students' Motivation in Engineering Capstone Courses. Interdisciplinary Journal of Problem-based Learning .(2013)

[20] Masek, A \& Yamin, S. (2011). The Effect of Problem-based Learning on Critical Thinking Ability: A Theoretical and Empirical Review. International Review of Social Sciences and Humanities, 2(1): 215-221.

[21] Chen, K. N., Lin, P. C., \& Chang, S. S. (2011). Integrating library instruction into a problembased learning curriculum. Aslib Proceedings, 63 (5), 517 - 532.

[22] Erick, D. G., \& Kolmos, A. (2003). Characteristics of problem-based learning. International Journal Engng Ed. 19 ( 5), 657 - 662.

[23] Hou, J. (2014). Project and Module Based Teaching and Learning. International Journal of Social, Behavioral, Educational, Economic, Business and Industrial Engineering, 8 (3), 791-796.

[24]Uno, H. B. (2012). Model Pembelajaran: Menciptakan Proses Belajar Mengajar yang Kreatif dan Efektif. Jakarta: Bumi Aksara.

[25] Sudjana, N. (2010). Penilaian Hasil Proses Belajar Mengajar. Bandung: PT. Ramaja Rosdakarya.

[26] Watson, P. (2002) The role and integration of learning outcomes into the educational process. Active Learning in Higher Education, 3(3), 205-219.

[27] Kettunen, J., Mertanen, L. K., \& Penttila, T. (2013). Innovation Pedagogy and Desired Learning Outcomes in Higher Education. On The Horison, 21 (4), 333-342.

[28] Wahidmurni, dkk. (2010). Evaluasi Pembelajaran. Yogyakarta: Nuha Litera.

[29] Carenys, J., Moya, S., \& Perramon, J. (2016). Is It Worth It to Consider Videogames in Accounting Education? A Comparison of Simulation and A Videogames in Attributes, Motivation, and Learning Outcome. Spanish Accounting Review. 1-13.

[30] Suarsana, I. M., \& Mahayukti, G. A. (2013). Pengembangan E-Modul Berorientasi Pemecahan Masalah untuk Meningkatkan Keterampilan Berpikir Kritis Mahasiswa. Jurnal Pendidikan Indonesia, 2 (2), 264 - 275. 
[31]Loyens, S.M., Jones, S.H., Mikkers, J \& Gog, T.V. (2015). Problem-based Learning as a Facilitator of Conceptual Change. Journal of Learning and Instruction 38:34-42.

[32] Arends, R. I. (2008). Learning to Teach Belajar untuk Mengajar Edisi 7 Jilid 1. Terj. H.P. Soejipto \& S. M. Soejipto. Yogyakarta: Pustaka Belajar.

[33] Suharta \& Luthan, P. L. A. (2013). Application of Cooperative Problem-based Learning Model to Develop Creativity and Foster Democracy, and Improve Student Learning Outcomes in Chemistry in High School. Journal of Education and Practice, 4 (25), 55-60.

[34] Hafsah, N. R. J., Rohendi, D., \& Purnawan. (2016). Penerapan Media Pembelajaran Modul Elektronik Untuk Meningkatkan Hasil Belajar Peserta didikPada Mata Pelajaran Teknologi Mekanik. Journal of Mechanic al Engineering Education, 3 (1), 106 - 112.

[35] Prastowo, A. (2015). Panduan Kreatif Membuat Bahan Ajar Inovatif. Jogjakarta: DIVA Press [36] Daryanto. (2013). Inovasi Pembelajaran Efektif. Bandung: Yrama Widya. 